\title{
Spermatozoal antibodies in cervical mucus
}

\author{
H. J. T. Coelingh Bennink; and A. C. Menge \\ Center for Research in Reproductive Biology, Department of Obstetrics and Gynecology, University of Michigan Medical Center, \\ Ann Arbor, Mich., U. S. A.
}

COELINGH BENNINK, H. J. T. and MENGE, A. C. (1974): Spermatozoal antibodies in cervical mucus. Europ. I. Obstet. Gynec. reprod. Biol., 4/4, 147-152.

The indirect immunofluorescent technique performed on spermatozoa provides a suitable method for detecting spermatozoal antibodies in cervical mucus. Blood sera and preovulatory cervical mucus samples from 13 women with infertility of unknown origin were tested extensively with this technique. Spermatozoal antibodies in cervical mucus were detected in 3 out of 13 patients. The specificity of these antibodies was shown to be IgA in two cases and IgG in the third case. One IgA antibody was also present in the blood serum of this particular patient, however in a low titer (1:4). Blood serum from the patient with an IgG antibody in cervical mucus contained the same antibody in a high titer $(1: 64)$. The results werecompared to the concentration of immunoglobulins in cervical mucus. In view of present knowledge our data are consistent with the following theories about circulating spermatozoal antibodies. IgA antibodies result from local immunization in the female genital tract and may leak to the general circulation. IgG and IgM antibodies result mainly from general immunization. IgG antibodies may diffuse to female genital tract secretions when present in a sufficiently high concentration. IgM antibodies are rarely found in the female reproductive tract.

immunofluorescence; immunoglobulins; infertility; local immune response

\section{Introduction}

In an extensive review, Shulman (1972) presented the evidence concerning relationships between unexplained infertility and the presence of antibodies against spermatozoa in blood sera of women. Although sperm antibodies, demonstrated by different techniques (agglutination, immobilization, cytotoxicity, immunofluorescence), are found more often and/or in a higher titer in relation to infertility, the mere existence of these antibodies does

\footnotetext{
* Present address: Department of Obstetrics and Gynecology, University of Utrecht, University Hospital, Utrecht, The Netherlands.
}

not imply infertility. The considerable incidence of circulating sperm antibodies in control groups, fertile women and even pregnant women suggests the necessity to distinguish the relevant typs, titer or class of antibody causing immunological infertility.

It seems reasonable to consider the female genital tract as the site of action where sperm antibodies eventually exert their inhibiting influence on fertility. Compared to the knowledge about sperm antibodies in blood sera, astonishingly limited information is available about the presence of sperm antibodies in secretions of the female genital tract. The available reports all deal with cervical mucus, 
or cervicovaginal flushings. Parish, Carron-Brown and Richards (1967) found an IgG cytotoxic antibody in cervical mucus in 3 out of 48 infertile women. The antibodies were not demonstrable in their blood sera. Waldman, Cruz and Rowe (1972) detected sperm migration-inhibiting antibody in human cervicovaginal secretions from normal women, but more frequently in women with unexplained infertility and, confusingly, in pregnant women. The activity could be removed with antiIgM antiserum and was not present in blood sera from the same women. Eyquem and d'Almeida (1973) tested cervical mucus in 59 women with infertility of unknown etiology. In 7 women they demonstrated sperm antibodies by immunofluorescence and in 12 women they found spermatotoxic antibodies. No details about the techniques used or titer and class of the antibodies were given. Friedman and Shulman (1974) analysed cervical mucus extracts of 9 infertile women with sperm-agglutinating antibody in their blood sera. By the Kibrick method samples from 6 patients were positive; 8 women were positive by the Franklin Dukes immobilization method and in 1 woman agglutination was present by the modified Franklin Dukes method.

The immunofluorescent technique seems to have several advantages for comparing the presence of spermatozoal antibodies in cervical mucus and blood sera. First, it distinguishes different antigenantibody systems by immunofluorescence of different parts of the spermatozoa, i.e. acrosome, equator, postnuclear cap and main tailpiece, as described by Hjort and Hansen (1971). Recently Johnson and Menge (in press) found endpiece fluorescence as a distinct fifth type. Second, the diversity of possible immunofluorescent patterns makes the technique potentially suitable to compare antibodies found in blood serum and cervical mucus from the same patient. Titration of the antibody is possible. The use of monospecific antisera distinguishes the class of the antibody. Another advantage, considering the high viscosity of cervical mucus, is the use of fixed spermatozoa.

The aim of the present investigation was to make an effort to apply the indirect immunofluorescence technique to detect sperm antibodies in cervical mucus from infertile women. At the same time we analysed the blood sera of those women with the same technique to see if there was any correlation between sperm antibodies in their blood and in the cervical mucus. We also measured the level of the immunoglobulins in cervical mucus.

\section{Materials and methods}

Patients: Cervical mucus and blood were obtained from 13 women who visited the Obstetrics and Gynecology Clinics at the University of Michigan Medical Center because of infertility of unknown etiology, i.e. previous history without data explaining possibly decreased fertility; no abnormalities found by physical examination; an ovulatory menstrual cycle; a normal postcoital test; a normal hysterosalpingogram with patent oviducts; no abnormalities found by laparoscopy; no agglutinating or immobilizing antibodies in blood serum of woman or man and a fertile semen analysis in the male.

Materials: Cervical mucus was aspirated into an empty 1 cc TB sterile disposable syringe avoiding contamination with vaginal flora. All samples were drawn in the preovulatory phase of the menstrual cycle. Sometimes samples from several consecutive days were combined. At the same time blood was taken from the antecubital vein. Blood sera and whole cervical mucus were stored at $-20^{\circ} \mathrm{C}$ until use.

Indirect immunofluorescent technique: The method described by Hjort and Hansen (1971) was used with some minor modifications. The spermatozoa in $0.2 \mathrm{ml}$ of normal human semen, provided by a sperm donor and adjusted with saline to a concentration of $60 \times 10^{6}$ spermatozoa per $\mathrm{ml}$, were washed three times in $10 \mathrm{ml}$ saline with centrifugation at $750 \times \mathrm{g}$ for $10 \mathrm{~min}$. The washed spermatozoa were resuspended in saline and the suspension was adjusted to $0.2 \mathrm{ml}$. About $0.02 \mathrm{ml}$ of this suspension was put on a slide and a sperm smear was made. The smear was air dried. A circle with a diameter of 1 $\mathrm{cm}$ was marked on the slide. The dried spermatozoa were then fixed in absolute methanol for $30 \mathrm{~min}$, dried again and stored at $-20{ }^{\circ} \mathrm{C}$ until use. Storage of less than $4 \mathrm{wk}$ did not influence the antigenicity of the spermatozoa. When used, the slides were washed in phosphate-buffered saline (PBS; pH 7.5) for $15 \mathrm{~min}$. The area around the circle was blotted dry. A drop of serum, serum dilution or whole cervical mucus was added to the PBS 
on the encircled area. The preparations were left in a moist chamber at room temperature. Serum or serum dilutions were incubated for $1 \mathrm{~h}$. Cervical mucus was incubated under the same conditions for $20 \mathrm{~h}$. After these incubation periods the test fluids were rinsed away with PBS and washed in PBS for 20 min with a change of buffer after $10 \mathrm{~min}$. Again the area around the circle was blotted and the spermatozoa were incubated for $30 \mathrm{~min}$ with 1-2 drops of fluorescein-conjugated goat anti-human immunoglobulin (polyvalent or monospecific; $\mathrm{Hy}$ land Lab, Los Angeles, Calif., U.S.A.). The conjugate was rinsed away with PBS and washed for $30 \mathrm{~min}$ in PBS with changes of buffer after 10 and $20 \mathrm{~min}$. The surrounding area was blotted and coverslips were mounted with $90 \%$ glycerine (10\% PBS). Fluorescence was observed with a Zeiss microscope equipped with a halogen quartz lamp using an FITC interference and 530 secondary filter plus BG38 red suppressing filters.

Controls with buffer, a known negative and a known positive serum were included in each group. Cervical mucus was tested undiluted. Blood sera were always tested in dilutions of 1:4, 1:16 and 1:64. All three dilutions were tested with anti-polyvalent, anti-IgA, anti-IgG and anti-IgM conjugate.

Immunoglobulin concentration: $\operatorname{IgA}, \quad \mathrm{IgG}$ and IgM concentrations in whole cervical mucus were estimated by radial immunodiffusion on commercially available low concentration immunodiffusion plates (Hyland Lab).

\section{Results}

Blood sera: A summary of the type of antibodies, the titers and the specificity in the 13 blood sera analysed is given in Table I.

Cervical mucus: Spermatozoal antibodies were detected by the indirect immunofluorescent technique in cervical mucus of 3 out of 13 women with unexplained infertility. Patient GAJ showed an IgG antibody agairst the main tailpiece; patient HUR an IgA antibody against the postnuclear cap and patient SAN an IgA antibody against the main tailpiece. A long incubation time seems to be essential for cervical mucus. After 1 or $2 \mathrm{~h}$ incubation, only the IgA postnuclear cap antibody was detected.

Immunoglobulin concentrations in cervical mucus are shown in Table II. The lower limits of sensitivity of the method used are, for IgA $3.8 \mathrm{mg} \%$; for IgG $2.8 \mathrm{mg} \%$ and for $\operatorname{IgM} 4.0 \mathrm{mg} \%$. In this group of 13 women we found 3 cases with $\operatorname{IgA}$, 9 with IgG and none with IgM above these limits.

\section{Discussion}

The indirect immunofluorescent technique appears to be applicable to detect sperm antibodies in cervical mucus without manipulating the physicochemical properties of the mucus. Eyquem and d'Almeida (1973) found spermatozoal antibodies in cervical mucus with this technique, but they just mention this technique and do not describe how to perform it.

Normal values of immunoglobulin concentrations in cervical mucus as described in the literature are given in Table III. Waldman, Cruz and Rowe (1971), using the very sensitive radioactive single radial immunodiffusion technique, found IgM present in only $30 \%$ of the samples. Schumacher (1973) detected IgM occasionally in traces. This is in accordance with the negative results for IgM in our present study. These findings suggest that IgM 'leaks' occasionally and in small amounts from the general circulation to the cervical mucus. Therefore we consider it likely that IgM sperm antibodies in blood sera, whether they are agglutinating, immobilizing or demonstrated by immunofluorescence, are biologically of minor importance.

Schumacher (1973) studied the changes of immunoglobulins in cervical mucus during the menstrual cycle. He found a midcycle minimum for both IgA and IgG. The IgG/IgA ratio in the early proliferative and late secretory phase of the menstrual cycle were similar to the ratio in serum $(6: 1)$. In the preovulatory phase the $\operatorname{lgG} / \operatorname{IgA}$ ratio was approximately $2: 1$. We found in preovulatory samples the same ratio 2-3:1 although we detected IgA only in 3 out of 13 samples. In 2 of these 3 samples, positive for $\operatorname{IgA}$, we found $\operatorname{IgA}$ sperm antibodies (HUR and SAN). 
TABLE I Location, titer and specificity of sperm immunofluorescence with blood sera

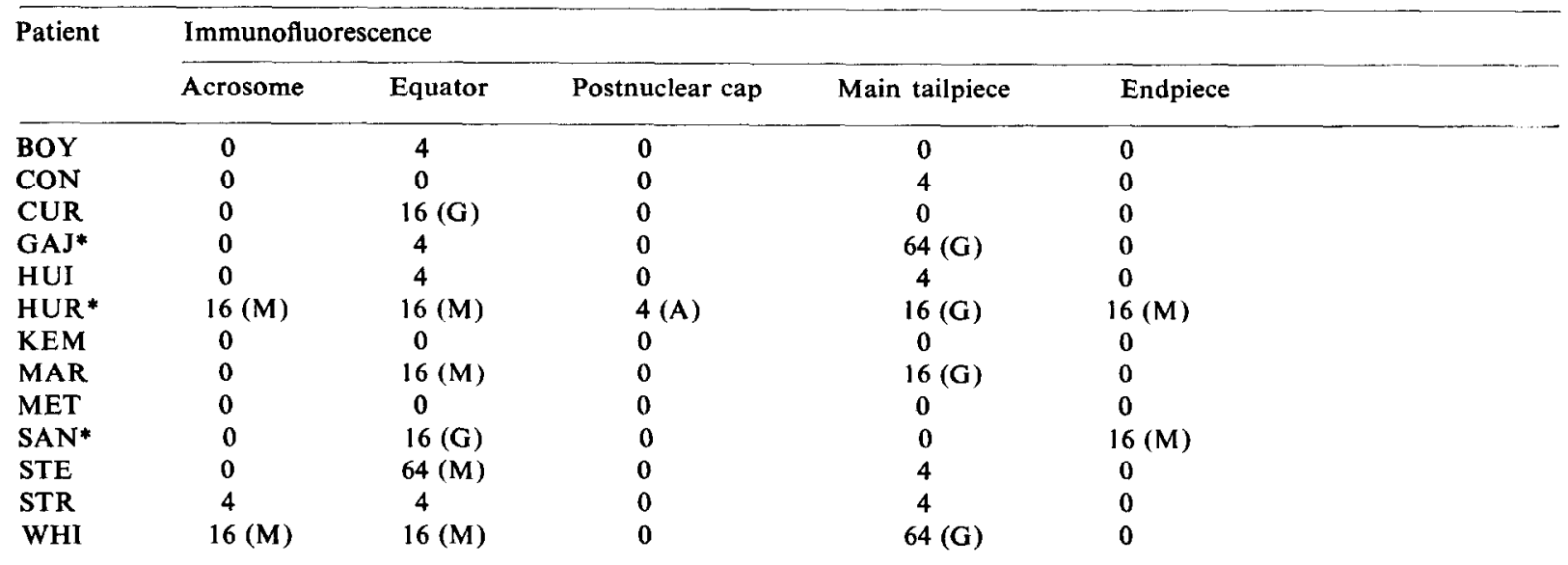

* Patients with spermatozoal antibody in cervical mucus. (Specificity was tested only in sera with a titer of 1:16 or higher.)

TABLE II Immunoglobulin concentrations in cervical mucus in $\mathrm{mg} \%$

\begin{tabular}{lcc}
\hline Patient & Ig A & Ig G \\
\hline BOY & - & 13.0 \\
CON & - & 13.9 \\
CUR & - & - \\
GAJ* & - & 10.4 \\
HUI & - & 3.5 \\
HUR* & 11 & 20.0 \\
KEM & - & 2.8 \\
MAR & - & - \\
MET & - & - \\
SAN* & 8.5 & 22.4 \\
STE & - & - \\
STR & 7.6 & 11.5 \\
WHI & - & 9.0
\end{tabular}

* Patients with spermatozoal antibodies in cervical mucus.
The low number of observations does not permit any conclusion about the immunofluorescent staining pattern with blood sera. Types and specificity of the sperm antibodies are in agreement with those described by Hjort and Hansen (1971), Hansen (1972), Jones and Ing (1974), and Johnson and Menge (in press). Acrosomal fluorescence appeared to be caused by IgM antibodies; equatorial fluorescence by both IgG and IgM antibodies, tail fluorescence by IgG antibodies and endpiece fluorescence by IgM antibodies. According to Hjort and Hansen (1971) a serum antibody titer of 1:16 or higher is significantly related to unexplained infertility. In our group 7 out of 13 patients had a titer of at least $1: 16$.

Our main interest in the type, titer and specificity of the spermatozoal antibodies in blood sera

TABLE III Normal immunoglobulin concentrations in $\mathrm{mg} \%$ in cervical mucus or cervicovaginal flushings

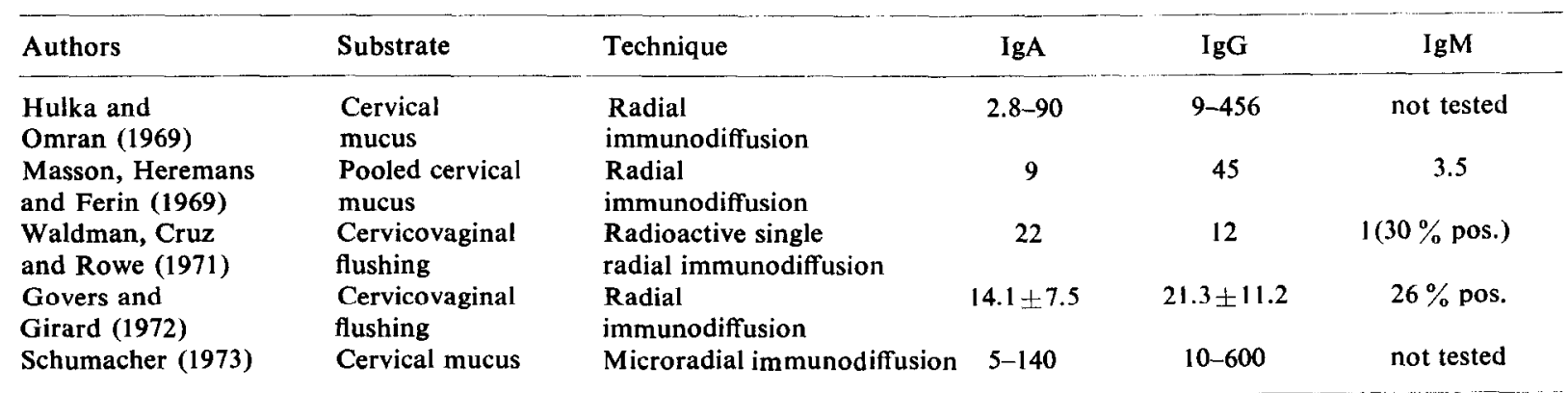


was in their relation to the same features in cervical mucus.

Patient GAJ showed tail fluorescence with blood serum caused by IgG antibody with a high titer of 1:64. In her cervical mucus we also found an IgG antibody directed against the spermatozoal tail. As the IgG concentration in preovulatory cervical mucus is about $1 \%$ of the blood concentration (Schumacher, 1973), this suggests that IgG sperm antibodies in blood sera have to overcome a dilution factor of about 1:100 to be recognized in cervical mucus. This might explain why only high blood titers are related to infertility.

The blood serum of patient HUR revealed sperm antibodies directed against all segments of spermatozoa. However, the unusual postnuclear cap antibody (Hansen, 1972), which was present in a lower titer $(1: 4)$ than all the other antibodies $(1: 16)$ in blood serum, was detected in her cervical mucus.

Patient SAN, with antibodies against the equatorial segment and the endpiece, but no tail fluorescence in her blood serum, showed IgA tail fluorescence with cervical mucus. This is a somewhat unusual specificity for tail fluorescence.

The findings in patients HUR and SAN suggest the possibility that their IgA sperm antibodies present in cervical mucus were produced locally with eventual leakage of antibody into the general circulation in patient HUR.

The cervicovaginal environment is part of a local secretory immune system. The concept of a distinct local immune system is characterized by the presence of a relatively high amount of $\operatorname{IgA}$ as secretory IgA (SIgA) in external secretions. SIgA consists of two IgA molecules bound by two glycoproteins called secretory component (SC) and J-chain (for a review see Tomasi, 1972). Intravaginal immunization against microorganisms followed by local synthesis of IgA or SIgA has been shown by several investigators (Waldman et al. 1971, Ogra and Ogra, 1973). Intravaginal immunization with seminal antigens has an immobilizing effect on spermatozoa in the Sims Hühner test (Strauss, 1965). Cervical tissue is capable in vitro of synthesizing $\operatorname{IgG}$ and $\operatorname{IgA}$ with an $\operatorname{IgG} / \operatorname{IgA}$ ratio of 2.3:1 (Behrman and Lieberman, 1973). Tourville, Ogra, Lippes and Tomasi (1970) localized $\operatorname{IgA}, \operatorname{IgG}$ and, much weaker, IgM in the female reproductive tract by direct immunofluorescence.
They also found secretory component in the luminal contents of many endometrial and cervical glands.

Based on these reports, a humoral local immune reponse in the female genital tract to the immunological challenge by semen seems a reasonable possibility. The presence of IgA sperm antibodies in the cervical mucus of two of our patients supports this idea. The IgG antibody in blood serum and cervical mucus of our third patient may support the theory that only high titers of circulatory sperm antibodies are relatived to infertility.

\section{References}

Behrman, S. J. and Lieberman, M. E. (1973): Biosynthesis of immunoglobulins by the human cervix. In: The Biology of the Cervix, pp. 235-249. Editors: R. J. Blandau and K. Moghissi. University of Chicago Press, Chicago, Jll.

Eyquem, A. and d'Almeida, M. (1973): Iso- and autospermantibodies in sterility. In: Immunology of Reproduction, pp. 344-350. Editors: K. Bratanov, R. G. Edwards, V. H. Vulchanov, V. Dikov and B. Somlev. Bulgarian Academy of Science Press, Sofia.

Friedman, M. R. and Shulman, S. (1974): Human cervical mucus and antibodies to spermatozoa. Fed. Proc., 33,814 .

Govers, J. and Girard, J. P. (1972): Some immunological properties of human cervical and vaginal secretions. Gynec. Invest., 3, 184.

Hansen, K. B. (1972): Immunofluorescent studies on human spermatozoa. III. Immunoglobulin classes of human spermatozoal antibodies. Clin. exp. Immunol., 10, 243.

Hjort, T. and Hansen, K. B. (1971): Immunofluorescent studies on human spermatozoa. I. The detection of different spermatozoal antibodies and their occurrence in normal and infertile women. Clin. exp. Immunol., $8,9$.

Hulka, J. F. and Omran, K. F. (1969): The uterine cervix as a potential local antibody secretor. Amer. J. Obstet. Gynec., 104/3, 440.

Jones, W. R. and Ing, R. M. Y. (1974): An immunofluorescent study of sperm isoimmunisation in infertile women. J. Obstet. Gynaec. Brit. Cwlth, 81, 385.

Masson, P. L., Heremans, J. F. and Ferin, J. (1969): Clinical importance of the biochemical changes in the female genital tract. I. Studies on the proteins of cervical mucus. Int. J. Fertil., $141,1$.

Ogra, P. L. and Ogra, S. S. (1973): Local antibody response to polio-vaccine in the human female genital tract. J. Immunol., 110/5, 1307.

Parish, W. E., Carron-Brown, J. A. and Richards, C. B. (1967): The detection of antibodies to spermatozoa and 
to blood group antigens in cervical mucus. $J$. Reprod. Fertil., 13, 469.

Schumacher, G. F. B. (1973): Soluble proteins of human cervical mucus. In: Cervical Mucus in Human Reproduction, pp. 93-113. Editors: M. Elstein, K. S. Moghissi and R. Borth. Scriptor, Copenhagen.

Shulman, S. (1972). Immunologic barriers to fertility. Obstet. Gynec. Surv., 27/8, 553.

Strauss, E. K. (1965): Sperm immobilization in the human vagina by induced muco-antibody. Fertil. and Steril., $16 / 3,346$.

Tomasi, T. B. (1972): Secretory immunoglobulins. New Engl. J. Med., 287/10, 500.
Tourville, D. R., Ogra, S. S., Lippes, J. and Tomasi, T. B. (1970): The human female reproductive tract: Immunohistological localization of IgA, IgG, IgM, secretory "piece", and lactoferrin. Amer. J. Obstet. Gynec. 108/7, 1102.

Waldman, R. H., Cruz, J. M. and Rowe, D. S. (1971): Immunoglobulin levels and antibody to candida albicans in human cervicovaginal secretions. Clin. exp. Immunol., 9, 427.

Waldman, R. H., Cruz, J. M. and Rowe, D. S. (1972): Sperm migration-inhibiting antibody in human cervicovaginal secretions. Clin. exp. Immunol., 12, 49. 